\title{
Application of Various Statistical Methods for Analyzing Escherichia coli and Dissolved Oxygen
}

\author{
Kim, Tae Jin*
}

\begin{abstract}
In 1996, Upper Oyster Creek (UOC) in Texas, USA was regarded as an improper river basin for water-related contact recreation and aquatic life use because of water quality problems. Therefore, in this study, Escherichia coli (E. coli) and dissolved oxygen (DO) data collected in the UOC between 2000 and 2011 were analyzed. A basic statistical comparison, time history plot, seasonal pattern analysis, and correlation analysis were applied to E. coli and DO; the E. coli concentration for the 2006-2011 period decreased compared with the E. coli concentration during 2000-2005 based on the time history plot and mean value. Based on the correlation analysis, it was determined that storm water runoff influences $E$. coli concentration. In addition, seasonal pattern analysis for two periods showed that the E. coli concentration between October and December is slightly greater than that between July and September period. Twenty-four hour DO data mean and minimum concentrations for 2000-2005 were $1 \mathrm{mg} / \mathrm{L}$ lower than those during 2006-2008 based on time history and data analysis results. These analyses provide a perspective view as well as ways to establish certain treatment controls and strategies for water-related contact recreation and aquatic life use in the UOC.
\end{abstract}

Key words : Correlation Analysis, Seasonal Pattern Analysis, Time History Analysis

\section{요 지}

미국 텍사스 주에 위치한 Upper Oyster Creek (UOC)는 수질문제로 인하여 1996년도에 물 관련 레크레이션과 수중생물에게 적합하지 않은 유역으로 판단되었다. 따라서, 본 연구에서는 2000년부터 2011년까지 UOC의 대장균과 용존산소 자료를 수집하였 으며 수집된 자료에 대하여 기본 통계 비교, 시계열 분석, 계절 패턴 분석 및 상관분석을 수행하였다. 시계열 분석과 평균값 비교를 통한2006년-2011년 대장균 농도가 2000년-2005년 대장균 농도보다 감소됨을 알 수 있었다. 도심 우수와 대장균 농도에 대한 상관분석을 수행하였으며 10 월부터 12월까지의 대장균 농도와 7월부터 9월까지의 대장균 농도에 대한 계절 패턴 분석을 통하여 10 월부터 12 월까지의 대장균 농도가 보다 높음을 알 수 있었다. 시계열 분석 및 평균/최소값 비교 결과에 따르면, 2000년-2005년 24시간 용존산소량 평균 농도와 최소농도는 2006년-2008년 용존산소량 평균농도 및 최소농도보다 1mg/L 낮게 분석되었다. 본 분석을 통해 Upper Oyster Creek에서의 물관련 레크레이션 및 수중생물을 위한 적절한 처리 방안을 수립하는데 필요한 자료를 제공하였다.

핵심용어 : 상관분석, 계절 패턴 분석, 시계열 분석

\section{Introduction}

Upper Oyster Creek is located in the Brazos River Basin, southwest of Houston, Texas, in northern Fort Bend County. It is identified as Segment 1245 in the Texas Surface Water Quality Standards (TCEQ, 2010) into three assessment units (AUs) subdivided by Texas Commission on Environmental Quality (TCEQ) shown in Fig. 1 and then first identified the impairment to the contact recreation and aquatic life uses for Upper Oyster Creek in the 1996 Texas Water Quality Inventory and 303 (d) List (TCEQ, 1996). The TCEQ has assessed Escherichia coli (E. coli) concentrations and dissolved oxygen (DO) concentrations for primary contract recreation use and aquatic life use, respectively. The conclusion is that the E.coli concentration is not supportive of the attainment of the Segment's primary contract recreation use and DO

*Corresponding Author, Member, Assistant Professor, Department of Civil Engineering, Daegu University

(Tel: +82-53-850-6526, Fax: +82-53-850-6529, E-mail: kimtj@daegu.ac.kr) 
concentration is less than optimal for attainment of Segment 1245's intermediate aquatic life use (TCEQ, 2007).

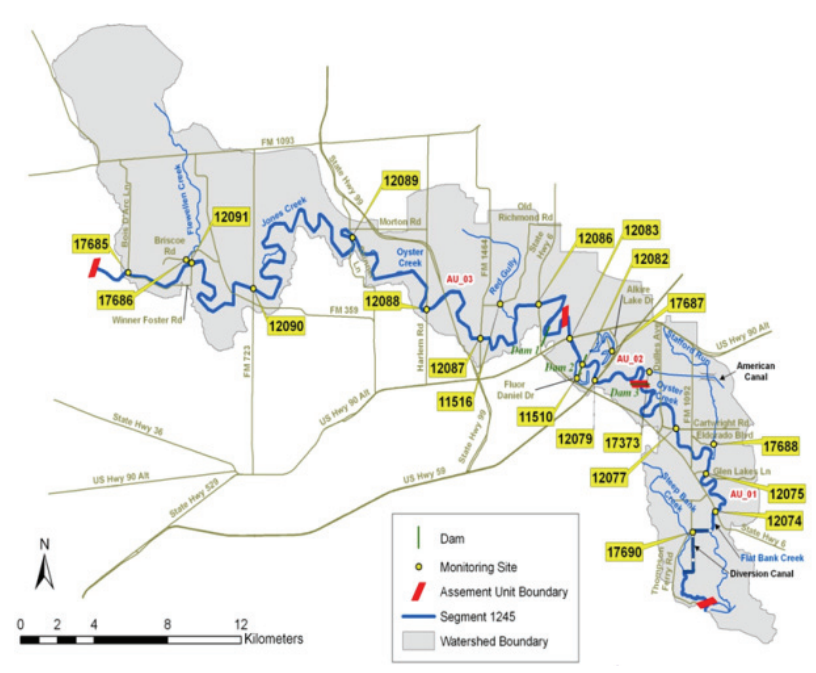

Fig. 1. E. coli. and Dissolved Oxygen Data Monitoring Stations in the Upper Oyster Creek

In this study, the water quality data for Segment 1245 was downloaded from both TCEQ Surface Water Quality Monitoring Information System (SWQMIS) (TCEQ, 2019) and the Brazos River Authority (BRA) Clean Rivers Programs (CRP) database (BRA, 2019). The data from the two databases were merged to eliminate duplicate entries. The query was restricted by date to those data collected from January 1 , 2000 to May 2011. The combined dataset was further reduced to the water quality parameters and relevant monitoring stations needed for this study. For data pertinent to the water quality TMDL, the primary parameter was E. coli and DO. Also, instantaneous streamflow measurement (when available), flow severity, associate field parameter data (dissolved oxygen, water temperature, $\mathrm{pH}$, and specific conductance), nutrient forms (total phosphorus, orthophosphate phosphorus, total Kjeldahl nitrogen, ammonia nitrogen, and nitrite + nitrate nitrogen), total suspended solids (TSS), and volatile suspended solids (VSS) are considered.

In addition, daily rainfall data were obtained for the period January 1, 2000 through December 31, 2010 from the National Oceanic and Atmospheric Administration National Climatic Data Center (NCDC) (NOAA NCDC, 2011). Rainfall data were obtained for these four meteorological stations: Clodine, Richmond, Sugar Land, and Three Rivers for possible use in subsequent analyses. With the use of the above data, this study provides analysis information of relevant water quality data (i.e. e. coli and DO) collected in Upper Oyster Creek (Hauck and Kim, 2011).
The time trends are investigated and collected data are compared. Various statistical methods such as correlation analysis and seasonal pattern analysis (Cowan, 1998) were applied to E. coli and DO data contained in the BRA CRP database and the TCEQ SWQMIS. Even though only 2000-2011 water quality related data that is out of data is used, the statistical data analysis applied in this study is enough to analyze the water quality problems phenomenon and can provide the various views to improve water quality problems in other similar basin that has DO decrease and E. coli increase. Also, water quality independent parameters used in this study and analysis procedures for results can be utilized in other basin because of the data used are surveyed in many other basin with little effort and time and analysis simplicity.

\section{E. coli and DO Review to Available Monitoring Stations}

Even though the number of $E$. coli data values was collected at several stations, this study focus on three stations 12090 , 12083 and 12074 because other stations have only 2002-2004 years data collection while these three stations have relatively long term data collection for 2002-2011 (Table 1). However, for 2006-2011 years, the sampling for E. coli has been limited to quarterly sampling at only three stations 12090,12083 , and 12074. Specifically, E. coli data collection occurred at several stations during 2004 during 12 sampling events, and these data are excluded from the dataset because the events were purposefully scheduled to capture certain biased conditions including wet weather. Various statistical analyses and graphical presentations of the $E$. coli data were performed to gain insight into spatial and temporal characteristics. The results of the data analyses are generally described in an upstream to downstream direction following the downstream flow of water. Also, analysis of the assessment unit (AU) shown in Fig. 1 are performed.

Unlikely E. coli data values were investigated at three stations, this study focus on only two stations 12090 and 12083 because no data available at station 12074 (Table 2). Also, no 24-hour DO data were available in the dataset for years 2009-2011. Even though the 24-hour DO data are represented as mean, minimum, and maximum values, the mean and minimum concentrations are more relevant to our purposes than the maximum value because the $\mathrm{DO}$ criteria are written in terms of the mean and minimum 24-hour concentrations and the criteria do not include a maximum. 
Table 1. E. coli $(\mathrm{MPN} / 100 \mathrm{ml})$ Number of Sampling and Summary for the Period 2000-2011 at Three Monitoring Stations

\begin{tabular}{|c|c|c|c|}
\hline \multirow{2}{*}{ Year } & \multicolumn{3}{|c|}{ Number of Sampling at Each Station } \\
\hline & 12090 & 12083 & 12074 \\
\hline 2000 & - & 1 & - \\
\hline 2001 & - & 3 & - \\
\hline 2002 & 3 & 6 & 3 \\
\hline 2003 & 9 & 12 & 9 \\
\hline 2004 & - & 2 & - \\
\hline 2005 & - & 4 & - \\
\hline 2006 & 4 & 9 & 4 \\
\hline 2007 & 4 & 8 & 4 \\
\hline 2008 & 4 & 4 & 4 \\
\hline 2009 & 4 & 4 & 4 \\
\hline 2010 & 4 & 4 & 4 \\
\hline 2011 & 2 & - & 2 \\
\hline & \multicolumn{3}{|c|}{ Basic Statistical Values at Each Station } \\
\hline Mean & 145 & 164 & 246 \\
\hline Min. & 3 & 4 & 13 \\
\hline Max & 5,500 & 22,000 & 82,000 \\
\hline
\end{tabular}

Table 2. DO Number of Sampling and Summary for the Period 2000-2011 at Two Monitoring Stations

\begin{tabular}{|c|c|c|c|}
\hline & \multirow{2}{*}{ Year } & \multicolumn{2}{|c|}{ Number of Sampling at Each Station } \\
\hline & & 12090 & 12083 \\
\hline & 2000 & - & - \\
\hline & 2001 & - & 5 \\
\hline & 2002 & - & 2 \\
\hline & 2003 & 5 & 8 \\
\hline & 2004 & 5 & 9 \\
\hline & 2005 & 5 & 7 \\
\hline & 2006 & - & 2 \\
\hline & 2007 & 4 & 4 \\
\hline & 2008 & 6 & 6 \\
\hline & 2009 & - & - \\
\hline & 2010 & - & - \\
\hline & 2011 & - & - \\
\hline & & \multicolumn{2}{|c|}{ Basic Statistical Values at Each Station } \\
\hline \multirow{2}{*}{ Mean } & $24 \mathrm{hr}$ mean data & 5.6 & 5.3 \\
\hline & $24 \mathrm{hr}$ min. data & 4.8 & 4.3 \\
\hline \multirow{2}{*}{ Min. } & $24 \mathrm{hr}$ mean data & 3.2 & 1.4 \\
\hline & $24 \mathrm{hr}$ min. data & 1.3 & 1.1 \\
\hline \multirow{2}{*}{ Max } & $24 \mathrm{hr}$ mean data & 11.2 & 11.4 \\
\hline & $24 \mathrm{hr}$ min. data & 9.2 & 9.4 \\
\hline
\end{tabular}

Various statistical analysis and graphical presentations of the 24-hour DO data were performed but the analyses are much more limited in scope than those performed for E. coli because of the paucity of recent DO data collected from 2006 to 2011. In this study, according to difference of sampling types, all sampling periods are divided into two periods as follows: periods 1 as 2002-2005 and period 2 as $2006-2011$. 


\section{Analysis Results}

E. coli are generally at low concentrations when water is impounded, because they will settle out of the water column when turbulence is low and are also killed by exposure to sunlight. The geometric mean, minimum and maximum concentrations of the all E. coli data at each monitoring station are provided in Table 1. Based on the criterion of $126 \mathrm{MPN} / 100 \mathrm{ml}$, the geometric mean concentrations at each station indicated nonsupport of the primary contact recreation use. However, these values do not mean the nonsupport of the primary contact recreation use of the Upper Oyster Creek. Plots of the time history of data are often useful for determining trends (Fig. 2). On each plot, the E. coli data points were indicated as being collected under either wet weather or non-wet weather conditions based on cumulative antecedent rainfall. The time history maintained year 2010 because of no available data for year 2011 .

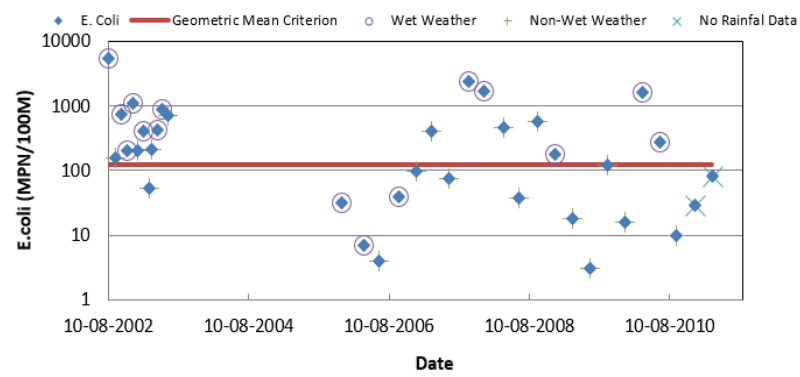

(a) Station 12090

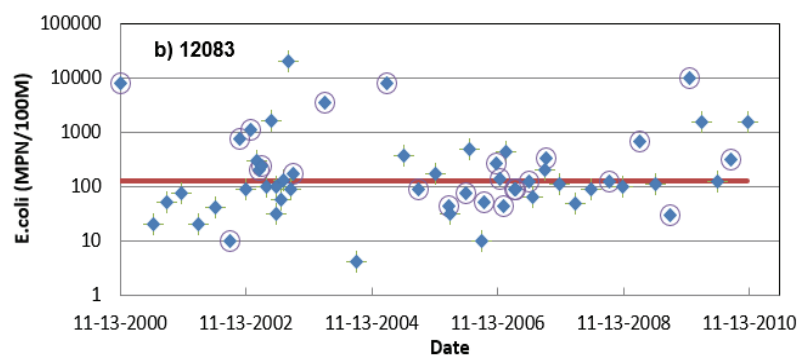

(b) Station 12083

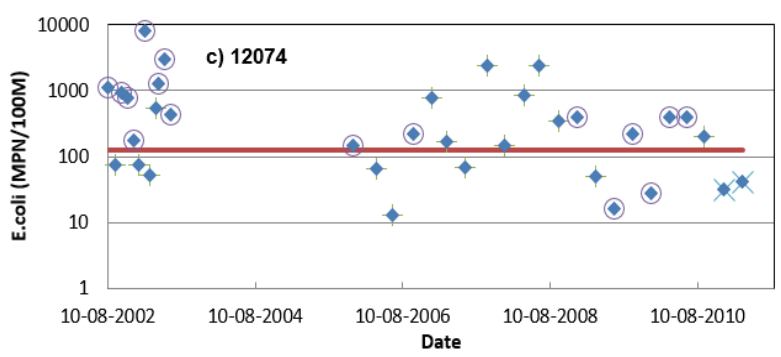

(c) Station 12074

Fig. 2. Time History Plot of E. coli Data at Stations 12090, 12083 and 12074
In this study, with the absence of instantaneous streamflow data for most data points, antecedent rainfall was used as a surrogate to indicate likely occurrence of elevated flows during the time of sampling. For all three stations cumulative rainfall was considered on the day of sampling and three antecedent days. However, for station 12090 the cumulative rainfall had to be $>0.3$ inches for a data point to be considered wet weather and $>0.1$ inches for stations 12083 and 12074 because of no criterion for determining the dry and wet weathers that depend on watershed characteristics. The more rural setting with less impervious cover for the watershed around station 12090 as compared to the more urban and more impervious cover for the watersheds immediately in the areas of stations 12083 and 12074 was the rationale for two rainfall thresholds. Because of high spatial variability in rainfall for any given storm and differences in response of runoff based on season of the year and days between rainfall events, rainfall does not represent a perfect surrogate to streamflow to indicate the hydrologic conditions under which sampling occurred.

With some exceptions data collected at all three stations under conditions considered as wet weather have high concentrations above the criterion of $126 \mathrm{MPN} / 100 \mathrm{~mL}$. In contrast, data collected under conditions indicated to be non-wet weather show wide variability with some data points below and some above the criterion. The time history plots indicate that at all three stations measured $E$. coli concentrations are generally lower in the 2005-2011 years than in 2002 and 2003 years, especially at station 12090. A partial explanation of these visually observable differences in concentrations is the frequency of data collected during wet weather conditions, with an appreciably higher frequency of wet weather data in the earlier years resulting in a greater occurrence of high concentrations. The data at all three stations also indicate that for the non-wet weather data there is a greater likelihood of low concentrations in more recent years than in the earlier years, especially at stations 12090 and 12074. These differences with time in E. coli concentration are even more apparent when the geometric mean concentration is determined separately by station for the earlier and recent data periods (Table 3 ).

When only the recent data from 2006-2011 is considered, the geometric mean concentration at station 12090 is less than the criterion. The geometric mean concentrations for all three stations show decreases in the more recent period from the means of the earlier period data. Seasonal variations in E. coli data are often difficult to show statistically because 
Table 3. Geometric Mean Concentrations at Three Stations for E. coli and DO Data

\begin{tabular}{c|c|c|c|c|c}
\hline \multirow{2}{*}{ Parameters } & \multicolumn{2}{|c}{ Stations } \\
\cline { 3 - 6 } & \multicolumn{2}{|c|}{ Periods } & 12090 & 12083 & 12074 \\
\hline \multirow{2}{*}{ E. coli $(\mathrm{MPN} / 100 \mathrm{~mL})$} & & $2000-2005$ & 427 & 185 & 513 \\
\cline { 3 - 6 } & & $2006-2011$ & 81 & 147 & 164 \\
\hline \multirow{2}{*}{ DO $(\mathrm{mg} / \mathrm{L})$} & \multirow{2}{*}{ 24-hour mean data } & $2000-2005$ & 5.2 & 5.3 & - \\
\cline { 3 - 6 } & \multirow{2}{*}{ 24-hour minimum data } & $2006-2011$ & 6.3 & 4.4 & - \\
\cline { 3 - 6 } & & $2000-2005$ & 4.5 & 4.1 & - \\
\hline
\end{tabular}

of the wide variations in concentrations experienced at most stations. The presence or absence of statistically significant differences in concentrations within a year, however, can have significance regarding implications on primary contract recreation use, which is more likely to occur during the warmer months than in cooler months. For example, if high E. coli concentrations above the criterion predominately occur during the cooler months and low concentrations below the criterion predominately occur during warmer months, then that information could have importance in determining whether or not a segment supports the primary contract recreation use.

This seasonal analysis was performed at the three stations 12090, 12083 and 12074 that have the longest record of data. Further, after 2006 year, E. coli data have only been collected in the months of February, May, August, and November. As a result of this pattern in the data, the seasonal analysis could not be performed by evaluating each month of the year, but was performed considering four seasons. As a first step, the $E$. coli data for each station was compared to the other two stations to determine if there were statistical significant differences in the population of data points at each station. No significant differences between the data for each station were found according to a Cochran T-test and Hartley's F-test (Cohen, 1988), allowing the data for each station to be combined into one large dataset for the seasonal analysis. The combined dataset of all three stations were separated into four seasons and then analyzed using Cochran T-test. Each E. coli data point was placed in the quarter representing the date of sample collection: Quarter 1 (January - March), Quarter 2 (April - June), Quarter 3 (July - September), and Quarter 4 (October - December). For $a=0.05$, a significant difference was determined between Quarter 3 and Quarter 4 populations, but no other seasonal comparisons showed any significant differences. The seasonal data are displayed graphically in Fig. 3 using box plots where the lowest mean and median concentrations are associated with Quarter 3 and the highest mean and median concentrations are associated with Quarter 4; the two quarters indicated to have differences in the measured E. coli data concentrations.

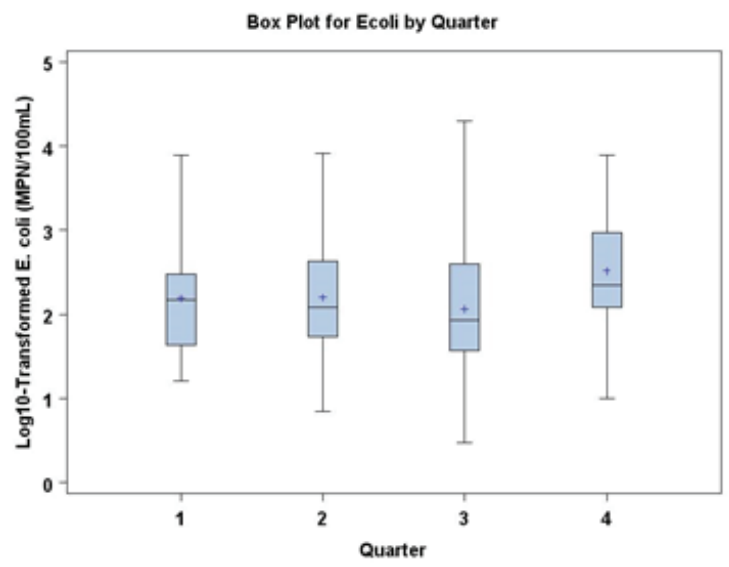

Fig. 3. Box Plots of Seasonal Data for Combined Data from Stations 12090, 12083, and 12074 (y-axis is in $\log 10$ scale where $0=1,1=10,2=100$, etc.)

To evaluate the relationship between various factors and E. coli concentrations, correlation analysis was performed for the three stations (stations 12090, 12083, and 12074) with long-term data. Linear regression methods employing least-squares criterion were used to perform the desired analysis. The correlation coefficient was used to evaluate the strength and direction (i.e., negative or positive correlation) of relationships between $E$. coli as the dependent variable and various independent variables. The correlation coefficient, $r$, is a measure of how well two sample populations vary jointly and can have values over the interval of -1.0 to 1.0. A value of $r$ close to +1 or -1 indicates a highly positive or negative degree of correlation and a good fit to a linear model, whereas a value of $r$ close to 0 indicates a poor fit to a linear model. For these analyses a weak, moderate, or good strength of linear relationship between two variables is defined by $r$ in the ranges. The weak, moderate, and good relationship were ranged from $-0.59(0.59)$ to 0.00 , from $-0.79(0.79)$ to -0.60 
(0.60), and from $-0.80(0.80)$ to $-1.00(1.00)$ in negative (positive) index, respectively (Cohen, 1988; Santhi et al., 2001; Van Liew et al., 2003). While linear regression analysis does not establish cause and effect responses, the approach does lend itself into gaining insights into relationships of $E$. coli to other variables within Upper Oyster Creek. These relationships can then be interpreted based on established responses from principles and observations of aquatic biology, water chemistry, and environmental engineering that indicate likely cause and effect responses and infer conditions favorable to the occurrence of elevated $E$. coli concentrations. For this analysis, unlike any of the prior analyses, the biased $E$. coli data collected in 2004 were included as data points. For correlation analysis the purpose is not to restrict the data to those values collected in an unbiased manner for assessment purpose, but rather to include data collected over as wide a variety of circumstances as possible to enhance the possibilities of discovering meaningful relationships of $E$. coli to other parameters. The independent parameters were limited to water quality constituents associated with a majority of the data points (i.e., parameters collected or sampled at the same time as the $E$. coli data collection). These constituents included total suspended solids, various numbers of cumulative antecedent rainfall as a surrogate for streamflow, and the basic field parameters of specific conductance, dissolved oxygen, dissolved oxygen percent saturation, $\mathrm{pH}$, and water temperature. Nutrient and streamflow data were not collected with many of the $E$. coli samples so these potential independent parameters were excluded from further consideration. Prior to performing the analysis, the E. coli data were all $\log$ transformed to minimize the effects of high concentrations in unduly weighting the correlation coefficient to artificially high values; an effect known statistically as occurring with "leverage points."

The results of the analysis were disappointing in the sense that only weak linear relationships were indicated at any station and for any independent parameter except for days since precipitation event for station 12090 and day 3 cumulative antecedent rainfall at station 12074, which showed barely moderate strength of relationships (Table 4). The complexities of the hydrology of Upper Oyster Creek, which includes substantial amounts of water pumped from the Brazos River and the series of three small dams, is a likely cause of the low $r$ values that were determined. Not having an adequate set of instantaneous flow measurements, which precludes its inclusion as an independent parameter, also removed one suspected important parameter. Nonetheless, the consistency of the direction of the correlation for several independent parameters provides a weight of evidence that $E$. coli concentrations in general are higher at higher streamflows that are associated with stormwater runoff than at lower non-stormwater driven streamflows. These independent parameters include specific conductance, days since precipitation event, flow severity, and the cumulative antecedent rainfall parameters.

Specific conductance, which is a measure of the amount of dissolved salts in the water, is generally lowered by the diluting effects of stormwater. Hence, the negative $r$ value of the $E$. coli to specific conductance correlation is a possible response of higher bacteria concentrations and lower specific

Table 4. Correlation Coefficient (r) Values Associated with Linear Regression of E. coli

\begin{tabular}{|c|c|c|c|}
\hline \multirow{2}{*}{ Independent Parameters } & \multicolumn{3}{|c|}{ Stations } \\
\hline & 12090 & 12083 & 12074 \\
\hline Specific Conductance $^{1}$ & -0.266 & -0.572 & -0.518 \\
\hline Dissolved Oxygen $^{1}$ & -0.102 & 0.088 & -0.021 \\
\hline Dissolved Oxygen (percent of saturation) ${ }^{1}$ & 0.035 & -0.477 & -0.080 \\
\hline Days since precipitation event (days) & -0.609 & -0.448 & -0.300 \\
\hline Flow Severity $(1=$ no flow, $2=$ low, $3=$ normal, $4=$ flood, $5=$ high, $6=$ dry $)$ & 0.373 & 0.479 & 0.522 \\
\hline 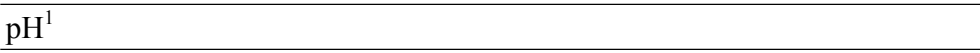 & -0.303 & -0.127 & 0.272 \\
\hline Total Suspended Solids ${ }^{2}$ & -0.087 & 0.235 & 0.270 \\
\hline Water Temperature $^{1}$ & -0.149 & -0.237 & -0.040 \\
\hline Day 0 cumulative antecedent rainfall, day 0 (day of sample collection) & 0.363 & 0.506 & 0.510 \\
\hline Day 1 cumulative antecedent rainfall, day $0+1$ day prior & 0.424 & 0.320 & 0.569 \\
\hline Day 3 cumulative antecedent rainfall, day $0+3$ days prior & 0.497 & 0.213 & 0.623 \\
\hline Day 5 cumulative antecedent rainfall, day $0+5$ days prior & 0.504 & 0.325 & 0.544 \\
\hline
\end{tabular}


conductance values under stormwater runoff conditions. Similar reasoning supports the consistently negative correlation of $E$. coli to the parameter of days since precipitation events, i.e., when bacteria data are collected further removed in time from a precipitation event influences of stormwater to raise concentrations are diminished. The consistently positive $r$ values associated with flow severity and the four cumulative antecedent rainfall parameters are more intuitive than the previous two parameters. That is, as flow severity increases and cumulative rainfall increases, the influence of stormwater runoff on increasing $E$. coli concentrations increases resulting in an anticipated positive $r$ value. However, again, none of the $r$ values for the relationship of $E$. coli to these independent parameters is even moderately strong, except days since precipitation at station 12090 and day 3 cumulative antecedent rainfall at station 12074. Rather it is more the consistency of the direction (negative or positive value) of the $r$ values to the direction of response should stormwater runoff generally increase $E$. coli concentrations that provides a weight of evidence supporting the cause and effect of increased E. coli concentrations under stormwater runoff conditions.

Total suspended solids (TSS) is a contrary parameter regarding $r$ values and the hypothesis regarding stormwater runoff, especially the very weak negative $r$ value at station 12090. The anticipated response would be that stormwater runoff not only carries increased levels of $E$. coli, but also increased levels of TSS as typically observed by the muddy water occurring during and after rainfall runoff events. Here the complexity of the hydrology likely masks the strength and even the sign of the anticipated relationship of $E$. coli to TSS, which would be positive $r$ values. However, the Brazos River is typically very muddy (i.e., high in TSS) and these muddy waters are pumped into Segment 1245 at its upstream end having their greatest influence on the most upstream of the three stations, 12090. It is not unreasonable to conclude that the generally high TSS concentrations associated with pumped Brazos River waters distorts the anticipated association of $E$. coli to TSS at station 12090. The high TSS values in the pumped waters and the general decrease in TSS concentrations in the downstream direction from the pump station due to settling of the solids was discussed in the technical support documents for the DO TMDL (Hauck and Du, 2007).

The mean and minimum 24-hour DO data for each station with 10 or more data points in Table 2 were summarized. The 24-hour mean DO data are presented as the average, minimum and maximum values for each station in Table 2. These basic statistics indicate that each station has an average for the 24-hour mean that is above the criterion of $4.0 \mathrm{mg} / \mathrm{L}$ set to protect the intermediate aquatic life use, but the minimum 24-hour mean value for each station is below the criterion. Similarly, the 24-hour minimum basic statistics are shown in Table 3; also showing averages above the 24-hour minimum criterion of $3.0 \mathrm{mg} / \mathrm{L}$ and minimum values below this criterion.

Plots of the time history of DO data are often useful for determining trends and also for visualizing how many data points do not meet the relevant DO criterion. For the present study the time period of data and amount of data are insufficient to warrant detailed analyses. The time history plots were developed for the two stations 12090 and 12083 (Fig. 4). The time history graphs for station 12090 indicate fewer excursions below the relevant numeric criterion for the data collected in 2007 and 2008 than the earlier data from 2003-2005, which is similar to the water quality improvement shown in the $E$. coli time history plot for the station. In contrast, the time history graphs for station 12083 indicate generally the same number of excursion for both the more recent (2006-2008) and earlier periods of data collection, which is somewhat similar to what was shown in the E. coli plot for this station. Actual comparisons of the average concentrations for the 24-hour mean and 24-hour minimum for the two time periods confirm what (Table 3) was observed in the time history plots. Both the 24-hour mean and minimum concentrations are approximately $1 \mathrm{mg} / \mathrm{L}$ higher at station 12090 for the more recent data collection period when compared to the earlier data period. For stations 21083 the comparisons of the two data collection periods indicate similar 24-hour mean and minimum concentrations for both periods.

\section{Summary and Conclusions}

The analyses of the E. coli data from January 2000 through May 2011 indicated three stations 12090, 12083, and 12074 with a consistent record of data going into 2011. Analysis to determine if there is a seasonal pattern to the $E$. coli data showed that the data were statistically higher in Quarter 4 (October - December) as compared to Quarter 3 (July September), though all other comparisons of the four quarters of the year showed no differences. Time history plots and basic computations of geometric mean concentrations indicate decreasing concentrations in the period 2006-2011 years when 

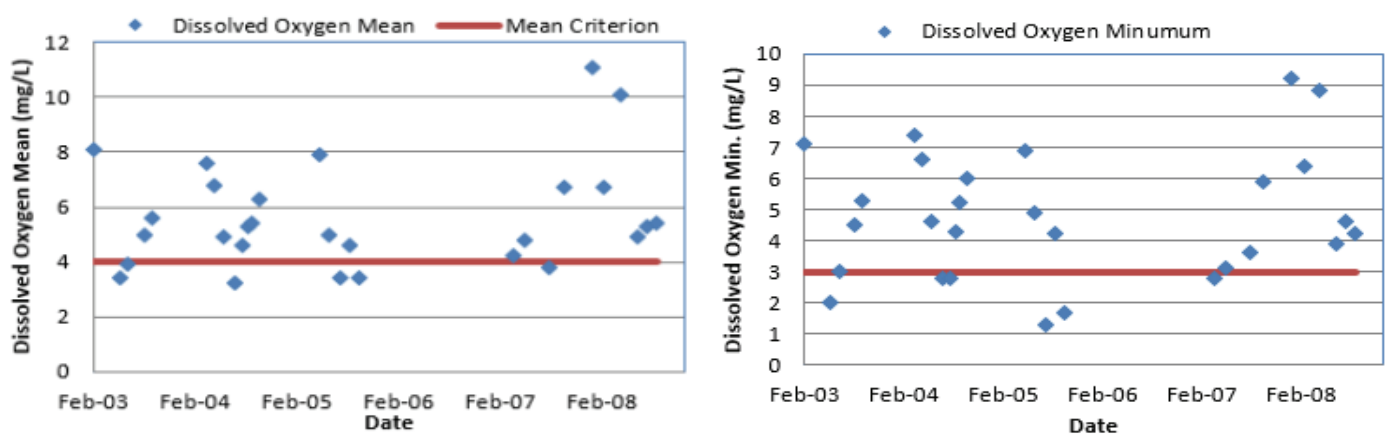

(a) Station 12090
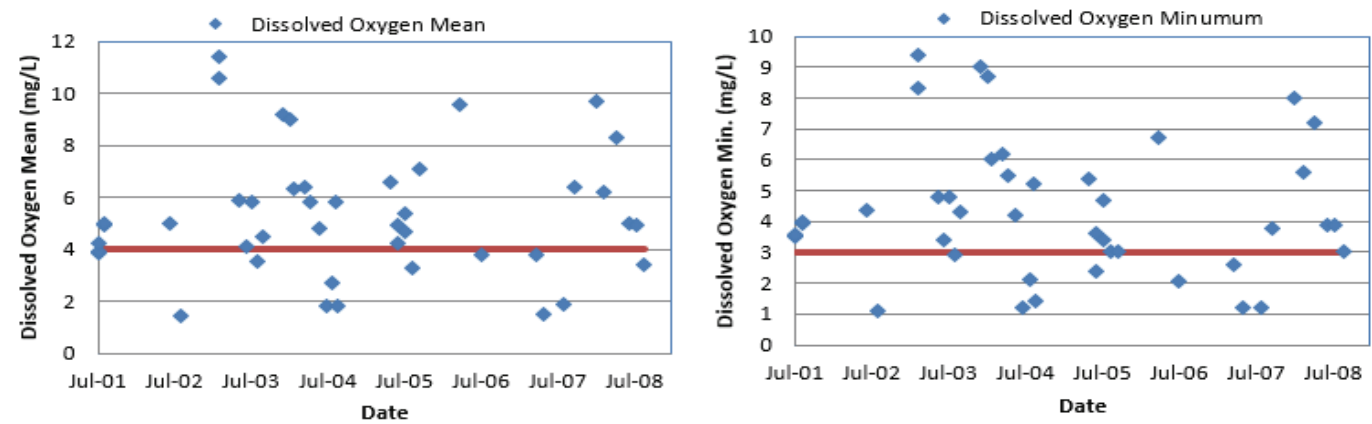

(b) Station 12083

Fig. 4. Time History Plot of DO Data at Stations 12090 and 12083

compared to the period of 2000-2005 years. This decreasing trend in E. coli concentrations is greatest at station 12090 and least at station 12083. Because of the absence of streamflow measurements to associate with $E$. coli data, it is impossible to make direct statements regarding occurrences of generally higher $E$. coli concentrations in association with stormwater runoff events than for data not associated with runoff influences. However, the weight of evidence from correlation analysis of E. coli to other parameters (e.g., flow severity observed by field crews collecting data, cumulative antecedent rainfall, and days since precipitation event) indicates that $E$. coli concentrations are most likely to be higher under the influence of stormwater runoff than when such influences are absent or diminished.

The analyses of the DO data from January 2000 through May 2011 indicated two stations 12090 and 12083 with a consistent record of data going into 2008. Within 2009-2011 years no 24-hour data were found in the databases searched for this study. Time history plots and comparisons of data based on separation into two time periods (2000-2005 and 2006-2008) show that both 24-hour mean and minimum concentrations are approximately $1 \mathrm{mg} / \mathrm{L}$ higher in the 2006-2008 period than the 2000-2005 period for station 12090 . In contrast, the time history plots and comparison of two time periods for station 12083 show roughly the same pattern and concentrations for both time periods. The lack of any data for the last three years limits the ability to draw conclusions regarding recent conditions for these two stations. To improve the analysis results of the relationship among several water quality data, selection of alternative analysis methods such as multiple linear regression is recommended with collection of water quality data with long periods that cover at least 20 years. With theses preparation, further analysis could be performed and provide more meaning analysis results. Due to available data constraint, the study has many difficult to analyze the DO and E. coli. However, the analysis results of this study has provided the insight of water quality improvement for water related contact recreation and aquatic life use since 1996. Also, the statistical analysis methods applied in this study can be used for other river basin that has similar water quality problems.

\section{Acknowledgments}

The author would like to acknowledge the contributions of Larry M. Hauck at Texas Institute for Applied Environmental Research. Most contents of this paper are reorganized and extracted from technical report of Hauck and Kim (2011).

This research was supported (in part) by the Daegu University Research Grant, 2016. 


\section{References}

Brazos River Authority (BRA). (2019). Retrieved January 19, 2019, from http://crpdata.brazos.org/

Cohen, J. (1988). Statistical power analysis for the behavioral sciences (2nd ed.) Hillsdale, NJ: Lawrence Erlbaum Associates. ISBN 0-8058-0283-5

Cowan, G. (1998). Statistical data analysis. Oxford: Clarendon Press.

Hauck, L.M., and Du, B. (2008). Upper Oyster Creek (Segment 1245) dissolved oxygen TMDL. Technical Report 0708, Texas Institute for Applied Environmental Research, Tarleton State University, Stephenville, TX.

Hauck, L.M., and Kim, T.J. (2011). Data analysis report: Bacteria and dissolved oxygen Upper Oyster Creek (Segment 1245). Technical Report 1104, Texas Institute for Applied Environmental Research, Tarleton State University, Stephenville, TX.

National Oceanic and Atmospheric Administration (NOAA) National Climatic Data Center (NCDC). (2011). Retrieved July 21, 2011, from http://www.ncdc.noaa. gov/oa/ncdc.html

Santhi, C, Arnold, J.G., Williams, J.R., Dugas, W.A., Srinivasan, R., and Hauck, L.M. (2001). Validation of the SWAT model on a large river basin with point and nonpoint sources. Journal of the American Water Resources Assocication, Vol. 37, No. 5, pp. 11691188.
Texas Commission on Environmental Quality (TCEQ). (1996). Texas water quality inventory and 303(d) list. Retrieved from https://www.tceq.texas.gov/ waterquality/assessment/02twqi/02categories.html

Texas Commission on Environmental Quality (TCEQ). (2007). One total maximum daily load for bacteria in Upper Oyster Creek Segment 1245. Retrieved January 12, 2019, from https://www.tceq.texas.gov/ assets/public/waterquality/tmdl/25oystercreek/25-up peroysterbacteria-approved-epa.pdf

Texas Commission on Environmental Quality (TCEQ). (2010). Texas surface water quality standards, 30 TAC 307 (2018 revision). Retrieved January 12, 2019, from https://www.tceq.texas.gov/assets/public/legal/ rules/rules/pdflib/307.pdf

Texas Commission on Environmental Quality (TCEQ). (2019). Retrieved January 19, 2019, from http://www. tceq.texas.gov/cgi-bin/compliance/monops/water_da ily_summary.pl

Van Liew, M.W., Arnold, J.G., and Garbrecht, J.D. (2003). Hydrologic simulation on agricultural watersheds: Choosing between two models. Trans. ASAE, Vol. 46, No. 6, pp. 1539-1551.

\begin{tabular}{l|l}
\hline Received & March 25, 2019 \\
\hline Revised & April 1, 2019 \\
\hline Accepted & May 22, 2019 \\
\hline
\end{tabular}

